\title{
The acute antinociceptive effect of hyperbaric oxygen is not accompanied by an increase in markers of oxidative stress
}

\author{
Shulin Liua,b, Donald Y. Shirachid, and Raymond M. Quock ${ }^{\mathrm{b}, \mathrm{c},{ }^{*}}$ \\ aDepartment of Diving Medicine, Second Military Medical University, Shanghai, China \\ ${ }^{b}$ Department of Pharmaceutical Sciences, College of Pharmacy, Washington State University, \\ Pullman, WA 99164, USA \\ 'Translational Addiction Research Center, Washington State University, Pullman, WA 99164, \\ USA
}

dDepartment of Physiology and Pharmacology, Thomas J. Long School of Pharmacy and Health Sciences, University of the Pacific, Stockton, CA 95211, USA

\begin{abstract}
Aims-Exposure to hyperbaric oxygen $\left(\mathrm{HBO}_{2}\right)$ causes an antinociceptive response in mice. However, breathing oxygen $\left(\mathrm{O}_{2}\right)$ at an elevated pressure can potentially cause oxygen toxicity. The aim of this study was to identify the determinants of $\mathrm{HBO}_{2}$ antinociception and the toxicity profile of $\mathrm{HBO}_{2}$.
\end{abstract}

Main methods-Male NIH Swiss mice were assessed for acute antinociceptive responsiveness under room air or $100 \% \mathrm{O}_{2}$ at 1.0 or 3.5 atmospheres absolute (ATA), using the acetic acidinduced abdominal constriction test. For the oxygen toxicity test, mice were exposed to 3.5 ATA oxygen for $11 \mathrm{~min}, 60 \mathrm{~min}, 60 \mathrm{~min}$ daily for 2 days $(120 \mathrm{~min}$ ) or $60 \mathrm{~min}$ daily for 4 days (240 $\mathrm{min}$ ), then assessed by analyzing the levels of two oxidative stress markers, MDA (malondialdehyde) and protein carbonyl in brain, spinal cord and lung.

Key Findings-Only the combination of $100 \% \mathrm{O}_{2}$ and 3.5 ATA caused significant antinociception. The antinociceptive effect of $100 \% \mathrm{O}_{2}$ was pressure-dependent up to $3.5 \mathrm{ATA}$. In the oxygen toxicity test, mice exposed to $\mathrm{HBO}_{2}$ for different time intervals had levels of brain, spinal cord and lung MDA and protein carbonyl that were comparable to that of control animals exposed to room air.

Significance-Treatment with $100 \% \mathrm{O}_{2}$ evokes a pressure-dependent antinociceptive effect. Since there was no significant increase in levels of the oxidative stress markers in the tested tissues, it is concluded $\mathrm{HBO}_{2}$ at 3.5 ATA produces antinociception in the absence of oxidative stress in mice.

(C) 2014 Elsevier Inc. All rights reserved.

"Corresponding author: Raymond M. Quock, Ph.D., Department of Pharmaceutical Sciences, College of Pharmacy, Washington State University, P.O. Box 6465134, Pullman, WA 99164-6534 USA, Tel: 509-345-5956, Fax: 509-335-5902, quockr@wsu.edu (R.M. Quock).

This work was presented in part at Experimental Biology 2013, Boston, Massachusetts, April 20-24, 2013.

Publisher's Disclaimer: This is a PDF file of an unedited manuscript that has been accepted for publication. As a service to our customers we are providing this early version of the manuscript. The manuscript will undergo copyediting, typesetting, and review of the resulting proof before it is published in its final citable form. Please note that during the production process errors may be discovered which could affect the content, and all legal disclaimers that apply to the journal pertain. 


\section{Keywords}

hyperbaric oxygen; antinociception; oxidative stress; malondialdehyde; protein carbonyl

\section{Introduction}

Hyperbaric oxygen $\left(\mathrm{HBO}_{2}\right)$ therapy has been approved by the FDA for a limited set of clinical indications [Gesell, 2008. However, there are a number of clinical reports whereby $\mathrm{HBO}_{2}$ therapy appears to be effective in a broader range of conditions, including several examples of chronic pain [Peach, 1995; Kiralp et al., 2004; Yildiz et al., 2004; Handschel et al., 2007]. There is clinical evidence for an analgesic effect of $\mathrm{HBO}_{2}$; however, the mechanism of this analgesic action is poorly understood.

There have been few animal studies exploring the efficacy of $\mathrm{HBO}_{2}$ in the relief of pain, and these have focused largely on the anti-inflammatory rather than antinociceptive effects of $\mathrm{HBO}_{2}$ [Warren et al., 1979; Sümen et al., 2001]. Other studies measured both antinociception and anti-inflammatory effects [Wilson et al., 2006]. However, the antinociception effect in this animal model did not manifest itself until nearly two hours after the $\mathrm{HBO}_{2}$ treatment.

We have reported that treatment of mice with $\mathrm{HBO}_{2} @ 3.5$ atmospheres absolute (ATA) resulted in a very rapid-onset antinociceptive effect (i.e., within $5 \mathrm{~min}$ ). However, whether this biological response is the effect of the $100 \%$ oxygen $\left(\mathrm{O}_{2}\right)$ or both is unclear. It is equally uncertain whether the antinociceptive effect is associated with an oxidative stress induced by reactive species of oxygen and nitrogen $\left(\mathrm{N}_{2}\right)$ as a result of $\mathrm{HBO}_{2}$ treatment [Thom, 2009].

The present study was conducted to determine the optimal conditions for expression of the antinociceptive response to acute exposure to $\mathrm{HBO}_{2}$, ascertain whether the antinociceptive effect was pressure-dependent, and assess the possible oxidative injury caused by our hyperbaric oxygen exposure.

\section{Materials and Methods}

\section{Animals}

Male NIH Swiss mice, weighing 18-22 g, were purchased from Harlan Laboratories (Indianapolis, IN) and used in these experiments, which were approved by an institutional animal care and use committee and carried out in accordance with The Guide for the Care and Use of Laboratory Animals, 8th Edition (National Academies Press, Washington, DC, 2010).

Mice were housed five per cage in the AAALAC-accredited Wegner Hall Vivarium with access to food and water ad libitum. The facility was maintained on a 12-h light:dark cycle (lights on $0700-1900 \mathrm{~h}$ ) under standard conditions $\left(22^{\circ} \mathrm{C}\right.$ room temperature, $33 \%$ humidity). Mice were kept in the holding room for at least four days following arrival in the facility and prior to experimentation. All measures to minimize pain or discomfort were taken by the investigators.

\section{Exposure to Hyperbaric Oxygen}

Five groups of eight mice each were treated with $0.6 \%$ glacial acetic acid, placed in the hyperbaric chamber, exposed to $100 \% \mathrm{O}_{2}$ at 1.0, 2.0, 2.5, 3.0 or 3.5 ATA for $5 \mathrm{~min}$, and assessed for antinociceptive responsiveness for $6 \mathrm{~min}$ for a total of $11 \mathrm{~min}$ of $\mathrm{HBO}_{2}$ treatment. Mice were placed in a B-11 research hyperbaric chamber (Reimers Systems, Inc., 
Lorton, VA) as previously described [Zelinski et al., 2009]. The chamber was ventilated with $100 \% \mathrm{O}_{2}$, U.S.P. (A-L Compressed Gases Inc., Spokane, WA) at a flow rate of $20 \mathrm{~L} /$ min to minimize nitrogen and carbon dioxide accumulation. The pressure within the cylindrical clear acrylic chamber $(27.9 \mathrm{~cm}$ diameter $\times 55.9 \mathrm{~cm} \mathrm{~L})$ was increased at a rate of 1.0 ATA $/ \mathrm{min}$ to the desired pressure and maintained for $11 \mathrm{~min}(5 \mathrm{~min}$ for onset of nociception plus $6 \mathrm{~min}$ antinociceptive testing). The mice were allowed to breathe spontaneously during $\mathrm{HBO}_{2}$ treatment. After completion of the $\mathrm{HBO}_{2}$ exposure, mice were then decompressed at a rate of $1.0 \mathrm{ATA} / \mathrm{min}$. Control groups of mice were exposed to room air, and experimental groups of mice were exposed to either compressed air (A-L Compressed Gases) or $100 \% \mathrm{O}_{2}$ circulated through the chamber at either 1.0 or 3.5 ATA and maintained for $11 \mathrm{~min}$. Decompression occurred as described above.

In determining whether the antinociceptive effect of $100 \% \mathrm{O}_{2}$ was pressure-related, the pressure of the $\mathrm{HBO} 2$ was varied at 1.0, 1.5, 2.0, 2.5, 3.0 and 3.5 ATA. In groups of control animals, the pressure of compressed air was set at 1.0, 2.0 or 3.5 ATA.

\section{Antinociceptive Testing}

Antinociceptive responsiveness was assessed using the abdominal constriction test as previously described [Zelinski et al., 2009]. Mice were treated i.p. with $0.1 \mathrm{ml}$ per $10 \mathrm{~g}$ body weight of $0.6 \%$ glacial acetic acid and placed into the hyperbaric chamber. Exactly $5 \mathrm{~min}$ later, the number of abdominal constrictions-lengthwise stretches of the torso with concave arching of the back-in each animal was counted for 6 min while under $\mathrm{HBO}_{2}$. Multiple raters were used for some but not all experiments; at least one of the raters was blinded to the drug treatment. All experiments were consistently conducted between 1300 and $1700 \mathrm{~h}$. The control reference group was exposed to room air. The degree of antinociception (inhibition of abdominal constrictions) produced in various treatment groups of mice was calculated as:

$\%$ antinociception $=100 \times \frac{\# \text { constrictions in control mice }-\# \text { constrictions in treated mice }}{\# \text { constrictions in control mice }}$

\section{Measurement of Lipid Peroxidation and Protein Carbonyl}

Mice were exposed to $\mathrm{HBO}_{2} @ 3.5$ ATA for $11 \mathrm{~min}, 60 \mathrm{~min}, 120 \mathrm{~min}$ (60 min daily for 2 days), $240 \mathrm{~min}$ (60 min daily for 4 days) or room air (eight mice were used for each treatment), then ketamine/xylazine anesthetized immediately after the final $\mathrm{HBO}_{2}$ exposure. Then the mice were perfused with phosphate buffered saline (PBS) containing heparin to remove the blood. The tissue was collected and resuspended with PBS containing $1 \mathrm{mM}$ EDTA and homogenized on ice at $50 \mathrm{mg} / \mathrm{mL}$. After spinning at $10,000 \times \mathrm{g}$ for $5 \mathrm{~min}$ at $4{ }^{\circ} \mathrm{C}$, the supernatant was collected for assay. Levels of malondialdehyde (MDA) were determined, using a commercially available colorimetric assay for lipid peroxidation (TBARS Assay Kit, Cayman Chemical Company, Ann Arbor, MI). The absorbance at 530$540 \mathrm{~nm}$ was measured to obtain the concentration of MDA. Protein carbonyls were measured using a commercially available quantitative protein $\mathrm{C}$ carbonyl assay kit (Cayman Chemical, Ann Arbor, MI). The sample to be assayed was homogenized in $50 \mathrm{mM}$ phosphate buffer containing $1 \mathrm{mM}$ EDTA, $\mathrm{pH} 6.7$, and then centrifuged at 10,000 $\times \mathrm{g}$ for 5 min under $4^{\circ} \mathrm{C}$. The supernatant was collected for assay. The protein concentration was determined using a BCA protein assay kit. The MDA content and protein carbonyl content were normalized to protein concentration for each sample. The purpose of the EDTA was to inhibit further production of these oxidative markers during the measurement process. Therefore, the oxidative marker levels in Tables 1 and 2 are tissues levels at the time of death. 
For the positive control, each sample from room air group were homogenized (with buffer without EDTA), centrifuged, and then incubated with $\mathrm{H}_{2} \mathrm{O}_{2}(5 \mathrm{mM})$, similar to Sewerynek et al. [1995]. Briefly, the homogenates were incubated with $\mathrm{H}_{2} \mathrm{O}_{2}$ for $60 \mathrm{~min}$ at $37^{\circ} \mathrm{C}$, then placed into ice for $10 \mathrm{~min}$ to stop the reaction. Then the homogenates were centrifuged at $13,200 \times \mathrm{g}$ for $5 \mathrm{~min}$ at $4^{\circ} \mathrm{C}$. The supernatants were collected for assay.

\section{Statistical Analysis of Data}

One-way ANOVA with a post-hoc Bonferroni multiple comparison test was used to compare the antinociception data and levels of MDA and protein carbonyl in groups exposed to different $\mathrm{HBO}_{2}$ regimens. Unpaired t-test was used to determine the difference between antinociceptive effects of $\mathrm{HBO}_{2}$ and compressed air at the same pressure.

\section{Results}

\section{Basic Characterization of $\mathrm{HBO}_{2}$-Induced Acute Antinociception}

Mice were randomly assigned to four different treatment groups: normobaric air (NBA; room air or compressed air @ 1.0 ATA), normobaric oxygen $\left(\mathrm{NBO}_{2}\right.$; room air replaced by $\left.100 \% \mathrm{O}_{2} @ 1.0 \mathrm{ATA}\right)$, hyperbaric air (HBA; compressed air @ $\left.3.5 \mathrm{ATA}\right)$ and hyperbaric oxygen $\left(\mathrm{HBO}_{2} ; 100 \% \mathrm{O}_{2}\right.$ @ 3.5 ATA). Fig. 1 shows that $\mathrm{NBA}, \mathrm{NBO}_{2}$ and $\mathrm{HBA}$ treatment groups had no demonstrable antinociceptive response. While in the $\mathrm{HBO}_{2}$ treatment group, increasing the pressure to 3.5 ATA resulted in a $93.8 \pm 2.2 \%$ antinociceptive effect. This was significantly different from all three control groups.

\section{$\mathrm{HBO}_{2}$-Induced Antinociception Is Pressure-Dependent}

Four groups of eight mice each were treated with $0.6 \%$ glacial acetic acid, placed in the hyperbaric chamber, exposed to $100 \% \mathrm{O}_{2}$ at 1.0, 2.0, 2.5, 3.0 or 3.5 ATA for $5 \mathrm{~min}$, and assessed for antinociceptive responsiveness for $6 \mathrm{~min}$ for a total of $11 \mathrm{~min}$ of $\mathrm{HBO}_{2}$ treatment. Fig. 2 shows a linear relationship between the pressure of the $\mathrm{O}_{2}$ exposure and the percent antinociceptive effect.

\section{Effect of $\mathrm{HBO}_{2}$ on Levels of Oxidative Stress Markers in Brain, Spinal Cord and Lung}

To determine whether the designed hyperbaric oxygen exposure caused oxidative injury in mice, the oxidative injury was assessed by analyzing the levels of two oxidative stress markers, MDA (malondialdehyde) and protein carbonyl in the brain, spinal cord and lung after $\mathrm{HBO}_{2}$ treatment @ 3.5 ATA for 11,60,120 or $240 \mathrm{~min}$. There were no significant differences in MDA and protein carbonyl levels between mice exposed to $\mathrm{HBO}_{2}$ and NBA mice in brain, lung and spinal cord (Table 1). The positive controls, on the other hand, showed a significant increase in levels of MDA and protein carbonyl.

\section{Discussion}

$\mathrm{HBO}_{2}$ therapy has been approved by the American Medical Association (AMA) and the Food and Drug Administration (FDA) for the treatment of the following fourteen conditions: air or gas embolism; carbon monoxide poisoning and smoke inhalation; carbon monoxide poisoning complicated by cyanide poisoning; clostridial myonecrosis (gas gangrene); crush injury, compartment syndrome and other acute traumatic ischemias; decompression sickness (the "bends"); enhancement of healing in selected problem wounds; exceptional blood loss (anemia); necrotizing soft tissue infections; refractory osteomyelitis; radiation tissue damage (osteoradionecrosis); compromised skin grafts and flaps; thermal burns; and idiopathic sudden sensorineural hearing loss [Gesell, 2008; Murphy-Lavoie et al., 2012]. But there are also clinical reports and anecdotal evidence of $\mathrm{HBO}_{2}$ efficacy in a much broader range of clinical conditions [Helms et al., 2011]. 
Although $\mathrm{HBO}_{2}$ treatment is not currently indicated in treatment of pain per se, $\mathrm{HBO}_{2}$ therapy is reported to induce an analgesic effect in relief of various types of pain in human subjects, including complex regional pain syndrome [Peach, 1995; Kiralp et al., 2004], fibromyalgia [Yildiz et al., 2004], headache [Wilson et al., 1998; Di Sabato et al., 1997], rheumatoid arthritis [Rui-Chang, 1994], chronic osteomyelitis [Handschel et al., 2007] and radiotherapy of cancer [Jones et al., 2006; Dall'Era et al., 2006]. The mechanism of this clinical analgesic effect of $\mathrm{HBO}_{2}$ treatment is not known, although some have attributed this effect of $\mathrm{HBO}_{2}$ to its anti-inflammatory properties [Weisz et al., 1997; Yang et al., 2006].

Animal studies related to $\mathrm{HBO}_{2}$ treatment of pain have been limited. Earlier studies focused largely on the anti-inflammatory rather than the analgesic effect of $\mathrm{HBO}_{2}$ [Warren et al., 1979; Sümen et al., 2001]. More recently, inflammatory pain induced by carrageenan in rats was evaluated after $\mathrm{HBO}_{2}$ exposure at 2.4 ATA for 90 min [Wilson et al., 2006, 2007]. $\mathrm{HBO}_{2}$ treatment was found to reduce inflammation (as determined by reduced paw swelling) as well as mechanical hypersensitivity (as determined by increased threshold for paw withdrawal) [Wilson et al., 2006]. The ability of $\mathrm{HBO}_{2}$ treatment to reduce inflammation and pain was comparable to that of acetylsalicylic acid treatment [Wilson et al., 2007].

In humans breathing air normally at sea level the alveolar $\mathrm{pO}_{2}\left(\mathrm{pAO}_{2}\right)$ is approximately 102 $\mathrm{mm} \mathrm{Hg}$ and breathing $100 \%$ oxygen it increases to $673 \mathrm{~mm} \mathrm{Hg}$. During $\mathrm{HBO}_{2}$ therapy the patient breathes $100 \% \mathrm{O}_{2}$ and the alveolar $\mathrm{pO}_{2}$ increases rapidly as the pressure in the hyperbaric chamber increases, so that at 2.0 ATA and at 2.5 ATA the $\mathrm{pAO}_{2}$ increases to $1433 \mathrm{mmHg}$ and to about $1813 \mathrm{mmHg}$ respectively, the latter a 17 -fold increase as compared to breathing air at 1.0 ATA [Jain, 1999]. These increases are attained within minutes, thus, the tissue $\mathrm{O}_{2}$ concentrations correspondingly increase in a rapid manner.

The onset of the antinociception in this study occurred within 5 minutes of the exposure of the mice to $\mathrm{HBO}_{2}$ and continued for another 6 minutes during the abdominal constriction test. It is possible that full antinociception may not have occurred within the 5 minutes of $\mathrm{HBO}_{2}$ exposure prior to the testing period, especially during the lower pressures applied during the pressure-response experiments. However, there did not appear to be any noticeable time difference between periods of abdominal constrictions in the animals, and the pressure-response curve was linear.

Oxygen toxicity is the main physiologic limitation on the use of $\mathrm{HBO}_{2}$-enriched breathing mixtures for medical applications and scientific, technical and military diving [Hampson and Atik, 2003]. It has been argued that oxidative stress is fundamental to $\mathrm{HBO}_{2}$ therapy [Thom, 2009]. Metabolic activation of molecular oxygen, as well as the chemical and physical interaction of cells with their environment, frequently give rise to reactive oxygen species (ROS), such as superoxide, hydrogen peroxide or singlet oxygen [Halliwell and Gutteridge, 1984]. Low levels of ROS result in an adaptation response by increasing cellular antioxidant activity. Higher levels that overwhelm the antioxidative capacity of the cells cause oxidative damage manifesting as protein oxidation, lipid peroxidation, DNA injury and membrane damage, eventually culminating in disease and death.

As our previous studies have routinely treated mice with $\mathrm{HBO}_{2}$ @ 3.5 ATA [Zelinski et al., 2009; Ohgami et al., 2009; Chung et al., 2010; Quock et al., 2011], we have to ascertain whether the $\mathrm{HBO}_{2}$ treatment induced oxidative stress. Lipid peroxides, derived from polyunsaturated fatty acids, are unstable and decompose to form a complex series of compounds, which include reactive carbonyl compounds, such as MDA [Esterbauer, 1985]. MDA is a naturally occurring product of lipid peroxidation. Lipid peroxidation is a wellestablished mechanism of cellular injury in both plants and animals and is used as an 
indicator of oxidative stress in cells and tissues and the measurement of thiobarbituric acid reactive substances (TBARS) is a well-established method for screening and monitoring lipid peroxidation [Yagi, 1998; Armstrong and Browne, 1994]. The most general indicator and, by far, the most commonly used marker of protein oxidation is protein carbonyl content [Stadtman and Oliver, 1991]. The most convenient procedure is the reaction between DNPH and protein carbonyl. DNPH reacts with protein carbonyls, forming a Schiff base to produce the corresponding hydrazone, which can be analyzed spectrophotometrically.

Our results showed that levels of both lipid peroxidation and protein carbonyl were not significantly increased after the $\mathrm{HBO}_{2}$ exposures, even following $\mathrm{HBO}_{2}$ @ 3.5 ATA for 60 min daily for 4 days. It is known that higher pressures and longer exposure times of $\mathrm{HBO}_{2}$ treatment can lead to oxygen toxicity to various organs, such as the brain [Liu et al., 2012] and the lung [Sun et al., 2011], but whether our exposure procedure produced oxygen toxicity was not previously known. $\mathrm{HBO}_{2}$ treatment can activate antioxidant as well as oxidant systems. Whether oxygen toxicity is induced depends on the balance of these antioxidant/oxidant systems. It would appear that our 11-min and 60-min $\mathrm{HBO}_{2}$ exposures didn't disrupt this balance. It is more interesting that even the daily 60 -min $\mathrm{HBO}_{2}$ treatments for 2 days or 4 days also failed to produce oxygen toxicity. Recently the preconditioning effect of $\mathrm{HBO}_{2}$ has been widely explored. It was found that $\mathrm{HBO}_{2}$ pretreatment could prevent oxidative injuries to organs [Yan et al., 2013; Liu et al., 2011]. Speit and Bonzheim [2003] implicated heme oxygenase-1 in $\mathrm{HBO}_{2}$-induced protection of A549 cells against oxygen toxicity induced by a second $\mathrm{HBO}_{2}$ treatment $24 \mathrm{~h}$ later. Recently it was reported that daily exposure to 90 min $\mathrm{HBO}_{2} @ 2.8$ ATA for as many as 40 days failed to significantly elevated levels of MDA, protein carbonyl and glutathionine peroxidase in the cerebral cortex, inner white matter and cerebellum [Simsek et al., 2012]. These findings, albeit at a lower atmospheric pressure than that applied in the present study, as well as our results are consistent in demonstrating a lack of oxygen toxicity. It is possible that in the present study, the 24-h interval between each $\mathrm{HBO}_{2}$ exposure prevent the accumulation of oxygen toxicity, but the adaptive and preconditioning actions induced by earlier $\mathrm{HBO}_{2}$ exposure(s) may contribute to these results.

We acknowledge that DNA damage is also an important marker of oxidative stress, and DNA strand breaks could be a site of oxidative damage from $\mathrm{HBO}_{2}$ exposure. Endogenous antioxidant levels are other important indicators of oxidative injury. These indictors should be measured when we further explore the oxidative/antioxidative status and the measurement of NO and other ROS would also accumulate our knowledge on this aspect. Also, this study was conducted in rodents and the results need to be reassessed when applied to humans.

\section{Conclusions}

The antinociceptive effect of $100 \% \mathrm{O}_{2}$ was pressure-dependent up to 3.5 ATA. Mice exposed to $\mathrm{HBO}_{2} @ 3.5$ ATA for $11 \mathrm{~min}, 60 \mathrm{~min}, 60 \mathrm{~min}$ daily for 2 days or $60 \mathrm{~min}$ daily for 4 days failed to show a significant increase in either protein carbonyl or MDA in the brain, spinal cord or lung. It is concluded that $\mathrm{HBO}_{2}$ at 3.5 ATA is able to produce significant antinociception without causing oxygen toxicity in mice. This also suggests that the $\mathrm{HBO}_{2}$-induced antinociception is not associated with oxidative stress.

\section{Acknowledgments}

This research was supported by NIH Grants GM-77153 and AT-007222 and funds from the WSU College of Pharmacy and the Chico Hyperbaric Center (Chico, California). 


\section{References}

Armstrong D, Browne R. The analysis of free radicals, lipid peroxides, antioxidant enzymes and compounds related to oxidative stress as applied to the clinical chemistry laboratory. Adv Exp Med Biol. 1994; 366:43-58. [PubMed: 7771281]

Chung E, Zielinski LM, Ohgami Y, Shirachi DY, Quock RM. Hyperbaric oxygen treatment induces a two-phase antinociceptive response of unusually long duration in mice. J Pain. 2010; 11:847-53. [PubMed: 20418186]

Dall'Era MA, Hampson NB, His RA, Madsen B, Corman JM. Hyperbaric oxygen therapy for radiation induced proctopathy in men treated for prostate cancer. J Urol. 2006; 176:87-90. [PubMed: 16753375]

Di Sabato F, Rocco M, Martelletti P, Giacovazzo M. Hyperbaric oxygen in chronic cluster headaches: influence on serotonergic pathways. Undersea Hyperb Med. 1997; 24:117-22. [PubMed: 9171470]

Esterbauer, H. Lipid peroxidation products: formation, chemical properties and biological activities. In: Poli, G.; Cheeseman, KH.; Dianzani, MU.; Slater, TF., editors. Free Radicals in Liver Injury. IRI Press; Oxford: 1985. p. 29-47.

Gesell, LB., editor. The hyperbaric oxygen therapy committee report: indications and results. 12. Durham: Undersea and Hyperbaric Medical Society; 2008.

Halliwell B, Gutteridge JMC. Oxygen toxicity, oxygen radicals, transition metals and disease. Biochem J. 1984; 219:1-14. [PubMed: 6326753]

Hampson N, Atik D. Central nervous system oxygen toxicity during routine hyperbarix oxygen therapy. Undersea Hyperb Med. 2003; 30:147-53. [PubMed: 12964858]

Handschel J, Brüssermann S, Depprich R, Ommerborn M, Naujoks C, Kübler NR, Meyer U. Evaluation of hyperbaric oxygen therapy in treatment of patients with osteomyelitis of the mandible. Mund Kiefer Gesichtschir. 2007; 11:285-90. [PubMed: 17786490]

Helms A, Evans AW, Chu J, Sahgal A, Ostrowski R, Sosiak T, Wolf G, Gillett J, Whelan H. Hyperbaric oxygen for neurologic indications-action plan for multicenter trials in: stroke, traumatic brain injury, radiation encephalopathy \& status migrainosus. Undersea Hyperb Med. 2011; 38:309-19. [PubMed: 22013758]

Jain, KK. Physical, physiological, and biochemical aspects of hyperbaric oxygenation. In: Jain, KK., editor. Textbook of hyperbaric medicine. Seattle: Hogrefe and Huber Publishers; 1999. p. 11-27.

Jones K, Evans AW, Bristow RG, Levin W. Treatment of radiation proctitis with hyperbaric oxygen. Radiother Oncol. 2006; 78:91-4. [PubMed: 16337705]

Kiralp MZ, Yildiz S, Vural D, Keskin I, Ay H, Dursun H. Effectiveness of hyperbaric oxygen therapy in the treatment of complex regional pain syndrome. J Int Med Res. 2004; 32:258-62. [PubMed: 15174218]

Liu S, Li R, Ni X, Cai Z, Zhang R, Sun X, Quock RM, Xu W. Perfluorocarbon-facilitated CNS oxygen toxicity in rats: reversal by edaravone. Brain Res. 2012; 1471:56-65. [PubMed: 22781141]

Liu Y, Sun XJ, Liu J, Kang ZM, Deng XM. Heme oxygenase-1 could mediate the protective effects of hyperbaric oxygen preconditioning against hepatic ischemia-reperfusion injury in rats. Clin Exp Pharmacol Physiol. 2011; 38:675-82. [PubMed: 21711378]

Murphy-Lavoie H, Piper S, Moon RE, Legros T. Hyperbaric oxygen therapy for idiopathic sudden sensorineural hearing loss. Undersea Hyperb Med. 2012; 39:777-92. [PubMed: 22670557]

Ohgami Y, Zylstra CC, Quock LP, Chung E, Shirachi DY, Quock RM. Nitric oxide in hyperbaric oxygen-induced acute antinociception in mice. NeuroReport. 2009; 20:1325-9. [PubMed: 19730405]

Peach G. Hyperbaric oxygen and the reflex sympathetic dystrophy syndrome: a case report. Undersea Hyperb Med. 1995; 22:407-8. [PubMed: 8574129]

Quock LP, Zhang Y, Chung E, Ohgami Y, Shirachi DY, Quock RM. The acute antinociceptive effect of $\mathrm{HBO}_{2}$ is mediated by a NO-cyclic GMP-PKG-K $\mathrm{ATP}$ channel pathway in mice. Brain Res. 2011; 1368:102-7. [PubMed: 20977894]

Rui-Chang, Y. Rheumatoid arthritis treated with HBO. Proc $11^{\text {th }}$ Int Congr Hyperb Med. San Pedro: Best Publishing; 1994. 
Sewerynek E, Melchiorri D, Ortiz GG, Poeggeler B, Reiter RJ. Melatonin reduces $\mathrm{H}_{2} \mathrm{O}_{2}$-induced lipid peroxidation in homogenates of different rat brain regions. J Pineal Res. 1995; 19:51-6. [PubMed: 8609595]

Simsek K, Ozler M, Yildirim AO, Sadir S, Demirbas S, Oztosun M, Korkmaz A, Ay H, Oter S, Yildiz $\mathrm{S}$. Evaluation of the oxidative effect of long-term repetitive hyperbaric oxygen exposures on different brain regions of rats. Scientific World Journal. 2012; 2012:849183.10.1100/2012/849183 [PubMed: 22454610]

Speit G, Bonzheim I. Genotoxic and protective effects of hyperbaric oxygen in A549 lung cells. Mutagenesis. 2003; 18:545-8. [PubMed: 14614191]

Stadtman ER, Oliver CN. Metal-catalyzed oxidation of proteins. Physiological consequences. J Biol Chem. 1991; 266:2005-2008. [PubMed: 1989966]

Sümen G, Çimşit M, Eroğlu L. Hyperbaric oxygen treatment reduces carrageenan-induced acute inflammation in rats. Eur J Pharmacol. 2001; 431:265-8. [PubMed: 11728435]

Sun Q, Cai J, Liu S, Liu Y, Xu W, Tao H, Sun X. Hydrogen-rich saline provides protection against hyperoxic lung injury. J Surg Res. 2011; 165:e43-9. [PubMed: 21067781]

Thom SR. Oxidative stress is fundamental to hyperbaric oxygen therapy. J Appl Physiol. 2009; 106:988-95. [PubMed: 18845776]

Warren J, Sacksteder MR, Thuning CA. Therapeutic effect of prolonged hyperbaric oxygen in adjuvant arthritis of the rat. Arthritis Rheum. 1979; 22:334-9. [PubMed: 426880]

Weisz G, Lavy A, Adir Y, Melamed Y, Rubin D, Eidelman S, Pollack S. Modification of in vivo and in vitro TNF-alpha, IL-1, and IL-6 secretion by circulating monocytes during hyperbaric oxygen treatment in patients with perianal Crohn's disease. J Clin Immunol. 1997; 17:154-9. [PubMed: 9083891]

Wilson HD, Toepfer VE, Senapati AK, Wilson JR, Fuchs PN. Hyperbaric oxygen treatment is comparable to acetylsalicylic acid treatment in an animal model of arthritis. J Pain. 2007; 8:92430. [PubMed: 17690013]

Wilson HD, Wilson JR, Fuchs PN. Hyperbaric oxygen treatment decreases inflammation and mechanical hypersensitivity in an animal model of inflammatory pain. Brain Res. 2006; 1098:1268. [PubMed: 16750177]

Wilson JR, Foresman BH, Gamber RG, Wright T. Hyperbaric oxygen in the treatment of migraine with aura. Headache. 1998; 38:112-5. [PubMed: 9529766]

Yagi K. Simple assay for the level of total lipid peroxides in serum or plasma. Meth Mol Biol. 1998; 108:101-6.

Yan W, Fang Z, Yang Q, Dong H, Lu Y, Lei C, Xiong L. SirT1 mediates hyperbaric oxygen preconditioning-induced ischemic tolerance in rat brain. J Cereb Blood Flow Metab. 2013; 33:396-406. [PubMed: 23299244]

Yang Z, Nandi J, Wang J, Bosco G, Gregory M, Chung C, Xie Y, Yang X, Camporesi EM. Hyperbaric oxygenation ameliorates indomethacin-induced enteropathy in rats by modulating TNF- $a$ and IL-1 $\beta$ production. Dig Dis Sci. 2006; 51:1426-33. [PubMed: 16838118]

Yildiz S, Kiralp MZ, Akin A, Keskin I, Ay H, Dursun H, Cimsit M. A new treatment modality for fibromyalgia syndrome: hyperbaric oxygen therapy. J Int Med Res. 2004; 32:263-7. [PubMed: 15174219]

Zelinski LM, Ohgami Y, Chung E, Shirachi DY, Quock RM. A prolonged nitric oxide-dependent, opioid-mediated antinociceptive effect of hyperbaric oxygen in mice. J Pain. 2009; 10:167-72. [PubMed: 18976963] 


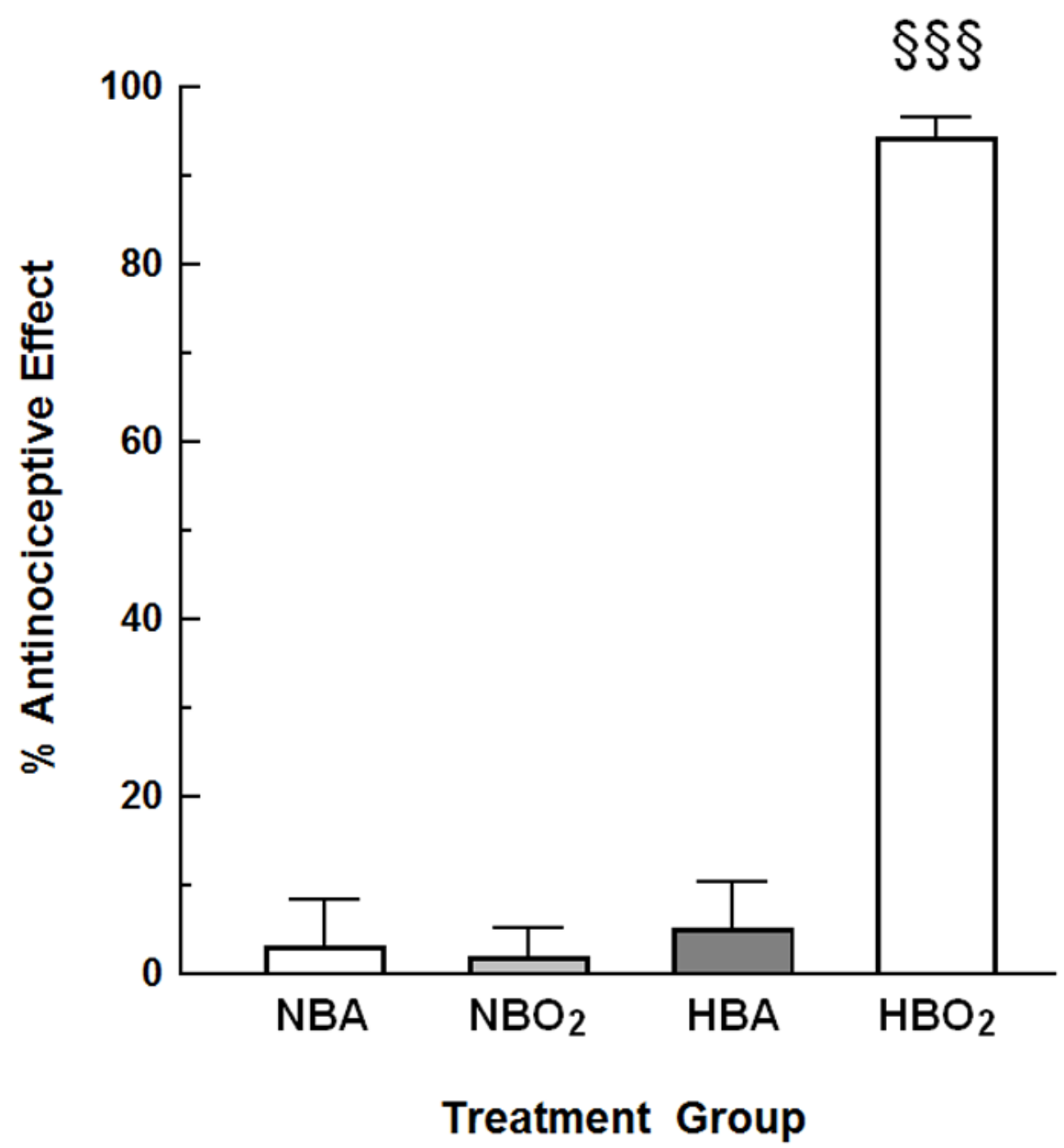

Fig. 1.

The effect of oxygen and/or hyperbaric pressure on nociception in mice. Groups: NBA, normobaric (room) air; $\mathrm{NBO}_{2}$, normobaric (100\%) oxygen; HBA, hyperbaric (room) air (3.5 ATA); and $\mathrm{HBO}_{2}$, hyperbaric oxygen (100\% oxygen at 3.5 ATA). The data are expressed as the mean \pm S.E.M. of $8-13$ mice per group. Significance of difference: $\S \S \S, \mathrm{P}<0.001$, compared to NBA, $\mathrm{NBO}_{2}$ and HBA treatment groups (one-way ANOVA and post-hoc Bonferroni's multiple comparison test). There were no significant differences among NBA, $\mathrm{NBO}_{2}$ or $\mathrm{HBA}$. 


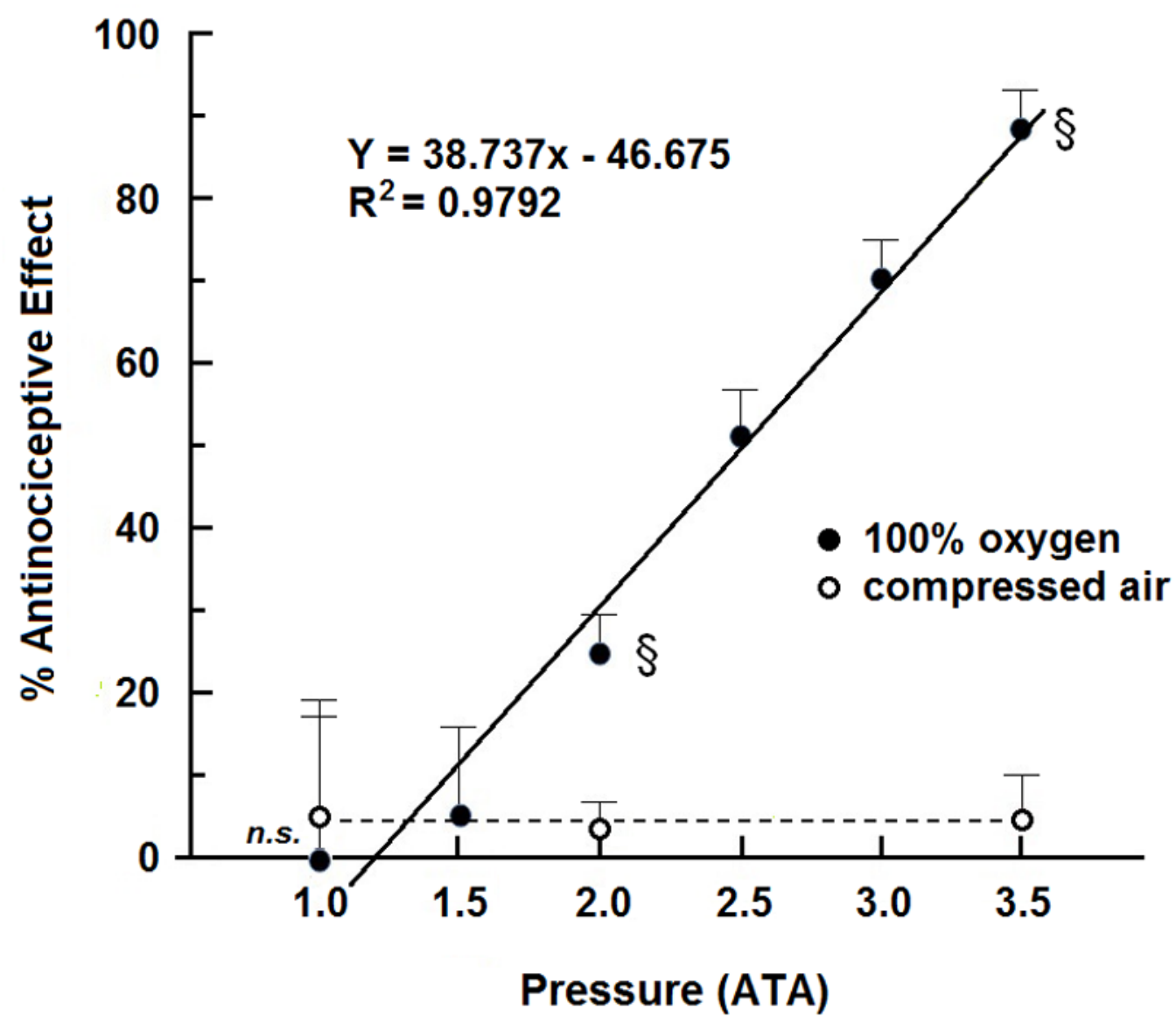

Fig. 2.

The influence of increasing pressure on oxygen-induced antinociceptive effect in mice. Each symbol (solid square for compressed air and solid diamond for $100 \%$ oxygen) represents the mean antinociceptive response of 8 mice at each pressure. The solid line shows the linear relationship between percent antinociceptive effect to $100 \% \mathrm{O}_{2}$ and pressure; the dotted line shows that pressure alone fails to evoke an antinociceptive effect in mice exposed to compressed air. Significance of difference: $\S, \mathrm{P}<0.05$, n.s., not significant, compared to compressed air at the same pressure (unpaired t-test). 
